\title{
Three hundred years of the Royal College of Physicians of Edinburgh
}

\author{
RONALD H GIRDWOOD
}

During the week 6 to 11 September 1981 there will be celebrations in Edinburgh to commemorate the 300th anniversary of the granting to its college of physicians of a Royal Charter. Various related activities are taking place throughout the year, but over these six days, just after the Edinburgh Festival, arrangements have been made for a comprehensive programme of scientific and social events, starting with an ecumenical service in the historic Kirk of the Greyfriars.

The next day the Lord Provost of Edinburgh will perform the opening ceremony, and Lady Antonia Fraser will inaugurate a historical symposium by giving a paper on "Charles II-the father of his people." Participants in the week's programme have been drawn not only from fellows and members but also from representatives of other colleges and academies of medicine throughout the world, the University of Leiden, the Pharmaceutical Society of Great Britain, the Royal Botanic Garden, and the Scottish Society of the History of Medicine. Each day there will be some form of entertainment, the Castle will be floodlit, and even the floral clock in Princes Street Gardens (fig 1) has been specially redesigned in honour of the occasion.

In the seventeenth century, however, things did not run so smoothly, and, indeed, the physicians of Edinburgh were thwarted in their endeavours for more than 60 years.

\section{Royal Infirmary, Edinburgh EH3 9YW}

RONALD H GIRDWOOD, MD, FRSED, professor of therapeutics and clinical pharmacology, University of Edinburgh; consultant physician, the Royal Infirmary of Edinburgh

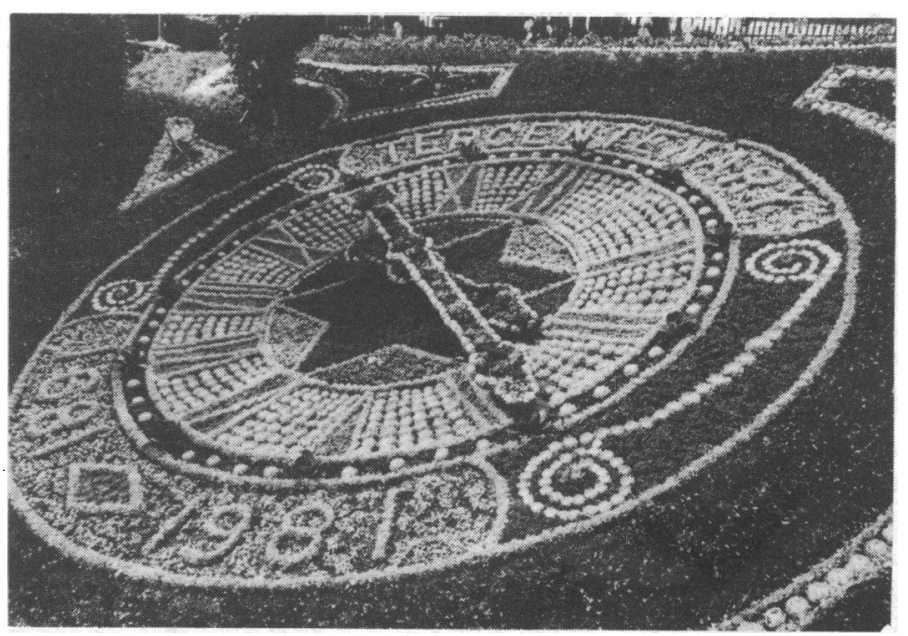

FIG 1-Floral Clock, Edinburgh, 1981.

\section{Early efforts to found a college}

In 1617, the year of the foundation of the Worshipful Society of Apothecaries in London, an attempt was made to found a college of physicians in Edinburgh. On 3 July of that year, James VI of Scotland (I of England) issued orders to the Scottish Parliament, directing that such a college should be established. This proposal was opposed by the Chancellors of the Universities of St Andrews (founded 1410), Glasgow (1451), and Aberdeen (1494), each of which, unlike Edinburgh, had an archbishop or bishop at its head. These universities had the power to award medical degrees on payment and without examination, and there may have been a fear that the proposed 
college would take over this function in Edinburgh. In that city the university had not been founded by the Church, but was known as the Tounis College (1583) or "The College of James VI," and it differed completely from the other Scottish universities and from the two in England in that it was under the control of a town council. The Incorporation of Surgeonapothecaries, itself closely connected with the town council, also opposed the formation of a college of physicians. In 1630 a second attempt, supported by Charles I, also failed, and, although Charles II had been proclaimed King of Great Britain and Ireland in Edinburgh six days after his father's execution, Oliver Cromwell sent a charter to the city in 1656 requiring the erection in Edinburgh of a "Society and College of Physicians of Scotland." This was opposed by the Scottish universities, Edinburgh Town Council, the Surgeons of Edinburgh, and the Faculty of Physicians and Surgeons of Glasgow, this last body being particularly upset by the suggestion that this would be a Scottish rather than an Edinburgh college.

\section{Successful negotiations}

In 1681 , at a time of great religious upheaval and bitterness in Scotland, a Royal Charter for a College of Physicians of Edinburgh was at last prepared and accepted, although not without opposition. It was signed by Charles II, the Great Seal being appended on 29 November of that year. The wording was designed to placate, so far as possible, all the various objectors. Much of the credit for the success of the negotiations was due to Robert Sibbald (1641-1722) whose uncle, Dr George Sibbald, had been largely responsible for the 1617 petition. The nephew had possession of his uncle's papers and knew of the delicate areas of contention. It was essential, for instance, to make it clear that medical degrees would not be awarded and that it would be an Edinburgh college, not a Scottish one.

It is perhaps surprising that any sensible and constructive negotiations could be concluded successfully in Edinburgh in 1681. This was a time of warfare, murders, assassinations, torture, and executions, largely carried out in the name of the Christian religion. James, Duke of York, the brother of Charles II, later to be James VII and II, came that year to Scotland as Commissioner. No Scottish Parliament had met for nine years, but James assembled one and insisted on the passage of various Acts, some of which increased the strife; one ensured that he, a Roman Catholic, would succeed to the throne. There was intense hostility between Presbyterians, Episcopalians, and Roman Catholics, with open warfare between the Covenanters and the Government troops. The churchyard of the Kirk of the Greyfriars, where the inaugural service for the Tercentenary Celebrations of the Royal College of Physicians will be held on 6 September 1981, was used as a prison for over 1000 half-clad, ill-fed Covenanters, who were defeated at the Battle of Bothwell Bridge in 1679 by Government troops under the Duke of Monmouth. Those who did not survive the ordeal lie in unmarked graves in the churchyard. The torture of others continued.

It was unity of medical purpose, however, not agreement in their religious views, that enabled Sibbald and his colleagues to succeed where others had failed. Robert Sibbald produced, for perusal by the Commissioner and by Charles II, the letter written by their grandfather, James VI, favouring the establishment of a college. The fourth Duke of Perth, a co-religionist with the royal duke, supported the scheme put forward by Sibbald, his family's physician. Above all, Sir Charles Scarburgh, a prominent fellow of the London college, and physician, in turn, to Charles II, James (VII and II), and William (II and III), influenced the negotiations favourably. The physicians' college in London, too, had had problems, having been instructed first by Charles II and then, on 29 March 1679, by the House of Lords" to expel "all such persons as should not receive the sacrament as protestants and subscribe to the oaths required by law." A meeting had been called to deal with this instruction, but conveniently there was no quorum for the comitia. ${ }^{1}$ Indeed, the London physicians had just been reinvigorated as a corporate body, and it was from this difficult state of affairs that Sir Charles Scarburgh came to Edinburgh as the physician to members of the royal family, including the Duke of York, and there met his friend Robert Sibbald. Scarburgh was very ready to do all he could to help persuade the High Commissioner and the King. ${ }^{2}$ This eminent London physician had studied under Harvey, as had Andrew Balfour, another of those pressing for an Edinburgh college. With all this support and with dwindling opposition, matters proceeded expeditiously in 1681. Of the founding fellows, who were 21 in number, 11 were graduates of the University of Leiden and six had been to other continental universities. ${ }^{2}$

\section{College premises}

At first, the meetings were held in the homes or lodgings of various fellows, and it was not until 1704 that there was purchased from a Sir James Mackenzie, for 3500 marks, his house and yards at the foot of Fountain Close in the High Street. A new building was erected, a portion being set aside for the treatment of the sick-poor. In $1775 \mathrm{Dr}$ William Cullen presided over the laying of the foundation stone of a building constructed in the Greek style at the east end of George Street, but the college could not afford the costs and sold it to the Commercial Bank of Scotland in 1843 for $£ 19700$. Again homeless, the college then obtained its present site at 9 Queen Street (fig 2).

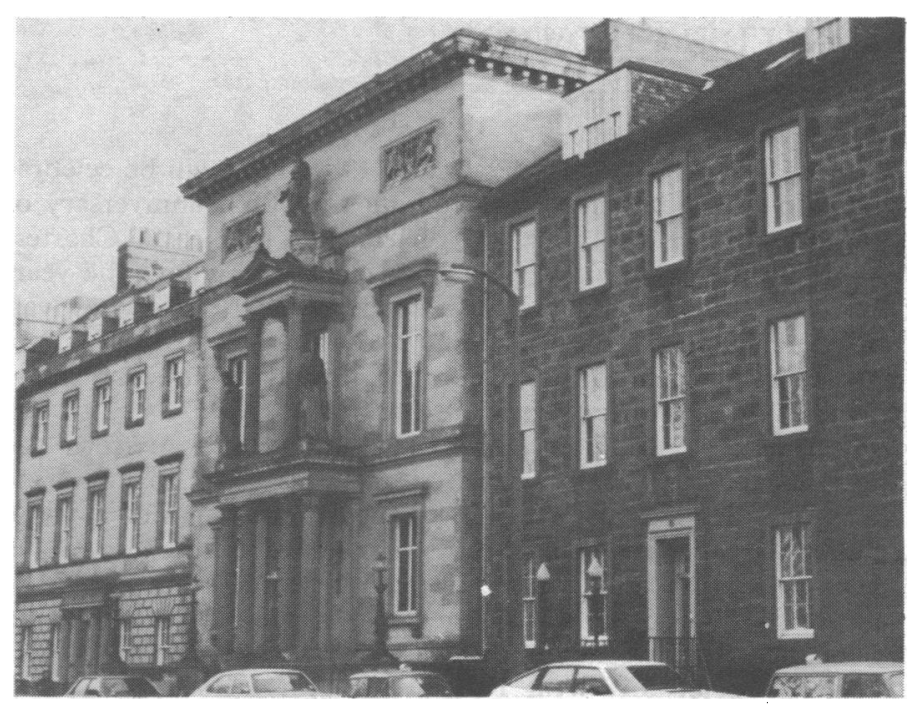

FIG 2-The Royal College of Physicians of Edinburgh.

The foundation stone for this was laid on 8 August 1844, two houses having first to be demolished. The present building has an impressive main central hall with 20 columns, which the casual observer might consider to be of real marble, but, unfortunately, this hall has to be used not only for college meetings and dinners but also for lectures and examinations. Even wedding receptions have been held there.

There have been additional contiguous buildings acquired on the east and west sides, the former being a most elegant house designed by Robert Adam and built in 1770. This was purchased in 1864. The less impressive building to the west of the main entrance contains office accommodation and various rooms, including bedrooms for visitors. It was acquired in 1970 and extensively altered within. There remains the need for a lecture theatre, and the college, which is so near the city centre, is at a major disadvantage because of the lack of car-parking facilities. 
Influence of the college on the faculty of medicine and the Royal Infirmary of Edinburgh

In 1692 Archibald Pitcairne, a founding fellow and an MD of Rheims, was appointed as professor of medicine in Leiden, and there his students included Boerhaave, later to become one of its most famous medical teachers, and John Monro of Edinburgh. The latter became Deacon of the Incorporation of Surgeons of Edinburgh and had the vision of a university medical school modelled on the Leiden pattern. John Monro was also determined that his son, Alexander, would play a key part in the new medical school, and, although there was as yet no faculty of medicine, Alexander Monro was appointed professor of anatomy in 1720. The most important figure in the development of Edinburgh as an international medical centre, however, was George Drummond, an ardent Jacobite, six times Lord Provost of the city, and a great friend of John Monro.

Times were hard in Scotland at the beginning of the eighteenth century. In 1698 feeling against England and William III was such that even war seemed possible. This was because of the failure of the Darien Scheme in which a Scottish trading company attempted to found a major colony in Panama with potentially very important commercial consequences. There was considerable opposition from England and Spain, in addition to casualties from disease: the scheme collapsed, and a bankrupt Scotland apportioned much of the blame to England. The college was fortunate in that it lost only $£ 80$ in the scheme. Luckily, passions were cooled, but the financial problems of the country and the wise decision that Scotland and England should not pursue opposing trading policies overseas were important background reasons for the signing of the Treaty of Union of 1707.

In relation to the possible establishment of a medical school and a teaching hospital, the forces behind this aim were now the fellows of the Royal College of Physicians (especially if trained in Leiden), John Monro and his son, the Incorporation of Surgeons, and, particularly after he became Lord Provost in 1725, George Drummond. They succeeded and the faculty of medicine of the university was established in 1726. The same group supported the acquisition of a house in 1729 to serve as a hospital before the building of a new Royal Infirmary. By 1705 the College of Physicians was examining on behalf of the university for the MD degree, the first graduate being David Cockburn, whose examination consisted of three parts carried out between 17 April and 1 May of that year. He was successful and was given his degree on $13 \mathrm{May} .^{3} \mathrm{By}$ the Royal Charter, however, he could not practise as a physician in the Edinburgh area without having a licence from the college, and this he acquired without fee or examination on 29 June. He was admitted as a fellow on 30 August.

\section{The Royal College of Physicians of Edinburgh as an international body}

George Drummond was determined to have an international medical school as one of the ways of halting the decline of the city that had lost its Parliament, Mint, and many members of the aristocracy. He succeeded, and an important consequence of his international outlook was that the faculty of medicine and the royal colleges in Edinburgh have never been parochial in their thinking. The faculty of medicine was intended to attract undergraduates not only from Scotland but also from England, Ireland, and North America, and did so, while the Royal College of Physicians has always considered that it should seek to benefit medical practice not only at home but world wide, and it is constantly interested in any suggestions as to how best it may do so. The Royal College of Surgeons of Edinburgh has a similar approach. In 1972 the Edinburgh College of Physicians had 542 fellows overseas and 920 at home. ${ }^{2}$ There were then 1969 overseas members, with 864 in the British Isles. At present there are 1214 fellows overseas and 1133 in these islands. It is perhaps because it was thought by some that the term "Royal
College of Physicians of Scotland" was, paradoxically, more parochial for an international body than "Royal College of Physicians of Edinburgh" that an opportunity to change the title in 1861 was not accepted.

John Morgan (1735-1809), an American who took the Edinburgh MD degree in 1763, was the first from his country to become a fellow of the college, his election taking place in 1765 . William Shippen (1736-1808), an MD (Edin) of 1761, became a fellow in 1768. These two, together with Benjamin Rush and Adam Kuhn, were responsible for founding America's first medical school at Philadephia. The College of Physicians of Philadelphia, founded in 1787, was modelled on the Edinburgh college and had eight Edinburgh graduates among its 24 initial fellows. Official representatives will attend the Tercentenary Celebrations. A more recent example of the overseas influence is that during 1927-63 all four professors of medicine at the University of Baghdad became fellows of the Edinburgh college. Wherever Edinburgh fellows and members travel they are likely to be made truly welcome by overseas physicians, who are delighted to keep in touch with home contemporaries from their college. In some areas there are local meetings. The impact of the college on medical care in various wars, including the 1745 rebellion, ${ }^{4}$ has been recorced elsewhere. ${ }^{2}$ Sir John Pringle (1702-82), for example, has been recognised as the father of military medicine.

\section{Other activities in the past}

\section{THE PHARMACOPOEIA}

Among the achievements of the college was the production of the Edinburgh Pharmacopoeia in 1699. This ran to 13 editions until 1841 and was replaced by the Pharmacopoeia of Great Britain and Ireland, produced by a committee with Sir Robert Christison, who had two periods as president of the college, as its chairman. Cowen ${ }^{5}$ has emphasised the direct role of the Edinburgh Pharmacopoeia as the progenitor of American pharmacopoeias.

\section{TEACHING}

In addition to teaching by the faculty of medicine, there has been much extramural teaching in Edinburgh, and in 1895 there was founded the School of M.edicine of the Royal Colleges. The extramural undergraduate clirriculum ceased in 1948, however, and the main teaching function of the college now relates to those already graduated, although most fellows in Edinburgh and surrounding districts participate in university teaching. The Edinburgh Post-Graduate Board for Medicine consists of representatives of the college, the Royal College of Surgeons of Edinburgh, and the university. Examinations continue to be held for the registerable qualification of LRCPEdin, LRCSEdin, LRCPSGlasg.

\section{THE LIBRARY}

The importance of the library can hardly be overemphasised. Founded in 1681 when Robert Sibbald gave about 100 volumes to provide its nucleus, it is now the largest medical library in Scotland and one of the largest in the United Kingdom. Among its many treasures is a copy of the first edition of the first book on medicine to be printed, the De Medicina of Celsus, published in 1478, the original having been produced about AD30. There is also a copy of the first edition of William Harvey's De Motu Cordis. The library, which is so large that it occupies several rooms, may be used by postgraduate students and other bonafide research workers. 


\section{VARIOUS ACTIVITIES}

A plaque at Waverley Station indicates the site of the physic garden, which was a precursor of the present Royal Botanic Garden, and which was taken over in 1676 by Balfour and Sibbald even before their college received its charter. In 1889 a laboratory was started for scientific research, ${ }^{6}$ enabling the college to keep well ahead as medical practice became increasingly based on scientific observation. It attracted both workers and specimens from all over the world, but the introduction of the National Health Service led to its closure in 1950, since it was no longer possible to maintain a comprehensive reporting service as a source of finance.

Other activities have included the setting up of dispensaries for the sick poor, the improvement of conditions in common lodging houses, the creation of orphanages, the promotion of the poor-laws, together with advice on many aspects of health, welfare, and medical education to governments and other bodies. Reports have been issued on the care of the elderly, mental illness, population control, drug addiction, and many other complex problems of the day. Regular symposia are held and their proceedings published. Colleagues in professions allied to medicine are welcome at many of these meetings. In 1972 the college, in conjunction with the other Royal Colleges of Physicians in the United Kingdom, played an important part in the creation of the faculty of community medicine.

In 1981, 300 years after the Royal College of Physicians of Edinburgh received its charter, it has been greatly honoured by visits from the Queen and the Duke of Edinburgh, and has both the Queen Mother and Prince Charles as honorary fellows. This exceptional recognition is much appreciated and is known to have been acclaimed by fellows, collegiate members, members, and licentiates throughout the world.
This account of the college is intended merely to indicate some of its history and activities in the past, subjects considered in detail in a large volume written by the late Professor W S Craig, ${ }^{2}$ and published in time for the Tercentenary Celebrations. Nevertheless, it is an occasion when all concerned with the welfare of the college must look rather to the future and aim to develop its activities both at home and overseas, using the past merely as a springboard for progressive activities in the future. Individual fellows and members have had a great influence on the development and progress of medical schools in the United Kingdom, North America, Australasia, Asia, and Africa, and on scientific research. There is no reason to doubt that their successors of today will play as important a part in medical progress in the twenty-first century as their predecessors have done in the past 300 years, working in harmony with their colleagues and with other medical bodies having a common purpose.

\section{References}

1 Clark G. A history of the Royal College of Physicians of London. Oxford: Clarendon Press, 1964:346.

2 Craig WS. History of the Royal College of Physicians of Edinburgh. Edinburgh: Blackwell Scientific Publications, 1976.

${ }^{3}$ Underwood EA. Boerhaave's men at Leyden and after. Edinburgh: Edinburgh University Press, 1977:98.

4 Girdwood RH. Medicines from Prince Charles Edward to Prince Charles. Edinburgh : Royal College of Physicians Publications, 1980.

5 Cowen DL. The Edinburgh Pharmacopoeia. In: Anderson RGW, Simpson ADC, eds. The early years of the Edinburgh Medical School. Edinburgh: Royal Scottish Museum, 1976:25-37.

${ }^{6}$ Ritchie J. History of the laboratory of the Royal College of Physicians of Edinburgh. Edinburgh: Royal College of Physicians Publications, 1953.

(Accepted 12 7une 1981)
Does vitamin $C$ in large doses (1-3 g) have any value in treating chronic infections?

The recommended daily intake of vitamin $\mathrm{C}$ for the United Kingdom (30 mg), which includes a built-in factor, is adequate to prevent or cure scurvy. ${ }^{1}$ Recently it has become recognised that vitamin $\mathrm{C}$ may have additional metabolic functions for which tissue concentrations greater than those provided by the recommended daily intake may be necessary. These extra-antiscorbutic functions include a role in lipid metabolism and atherogenesis, in cancer treatment, and in the protection against infection. Pauling, ${ }^{2}$ an originator of megadose treatment, has claimed that large doses of vitamin $\mathrm{C}$ provide a protection against infection, notably the common cold virus. Evidence in support of these claims is not convincing, but the results of trials show an appreciable reduction in the period of disability. The mode of action appears to be a non-specific effect on host resistance. There have, however, been no critical studies of the value of large doses of vitamin $\mathrm{C}$ in treating chronic infections, or of its possible action in enhancing the immune response. Hughes ${ }^{3}$ concluded that arguments in favour of megatherapy do not receive general acceptance; indeed, they may even be physiologically damaging as they increase the formation of oxalic acid, enhance the uptake of toxic metals (such as mercury), and increase the susceptibility to scurvy on cessation of long-continued high dosage.

\section{Department of Health and Social Security. Recommended daily amounts of food energy and nutrients for groups of people in the United Kingdom. London: HMSO, 1979. (Report on Health and Social Subjects No 15.) \\ 2 Pauling L.Vitamin C, the common cold and the flu. San Francisco: Freeman, 1976. Hughes RE. Vitamin C: some unresolved problems. In: Howard AN, ed.
Nutritional problems in modern society. London: John Libbey, 1981 .}

What antimalarial treatment is advised in patients with glucose-6phosphate dehydrogenase deficiency?

Patients with glucose-6-phosphate dehydrogenase deficiency who require antimalarial treatment may be treated as follows: (1) For Plasmodium falciparum malaria the standard treatment with chloroquine may be given, and there is little evidence that severe haemolysis occurs. (2) In chloroquine-resistant areas once again the standard treatment of quinine and pyrimethamine (Fansidar) seems to be effective and also devoid of any serious haemolytic complications. (3) In patients with $P$ vivax or $P$ ovale requiring radical treatment with primaquine, the chances of haemolysis are considerably reduced if a dose of $30 \mathrm{mg}$ primaquine is given weekly for eight weeks. This regimen seems to produce an adequate radical cure and considerably reduces the chances of haemolysis in most patients with G6PD deficiency. There is not enough experience of this regimen in G6PDdeficient patients with the $\mathrm{B}$ minus type of deficiency. Most of the experience of this weekly regimen in G6PD-deficient patients has been acquired from Africa and Thailand. It is extremely rare for chloroquine to cause haemolysis in such patients whether they are of the A minus or B minus type.

A 30-year-old woman with a mild manic-depressive temperament has been taking lithium tablets for a year. Should she be advised against marrying and having children?

The use of lithium is no bar to marriage: indeed, the effectiveness of lithium has improved the prognosis for affective disorder to a pronounced degree, enabling many to live normal lives. There is some evidence for a teratogenic effect, and it is wise to avoid pregnancy while lithium is being taken. ${ }^{1}$ If pregnancy is contemplated by a woman taking lithium it is best to confer with the psychiatrist responsible for the treatment so that the risks of withdrawal may be balanced against the risks of teratogenesis. One approach is to withdraw lithium for a trial period, and if there is no recurrence within the time span expected to continue to omit lithium until the puerperium. If another episode sufficiently severe to cause concern occurs lithium may be reinstituted and a further trial conducted later. If the risk of withdrawal is considered too high the relative risks of teratogenesis may be discussed with all concerned. Withdrawal of lithium for the first four months of pregnancy should be considered in order to minimise the risks. If lithium is given during pregnancy careful supervision and regular estimations of the serum lithium concentrations are necessary. The important aspects have been clearly described by Weinstein. ${ }^{1}$

Weinstein MR. Lithium treatment of women during pregnancy and in the postdelivery period. In: Johnson FN, ed. Handbook of lithium therapy. Lancaster MTP Press Ltd, 1980: chap 48. 